\title{
Correction to: Early sepsis markers in patients admitted to intensive care unit with moderate-to-severe diabetic ketoacidosis
}

\author{
Florian Blanchard ${ }^{1 *}+\left(\mathbb{0}\right.$, Judith Charbit ${ }^{2 \dagger}$, Guillaume Van der Meersch', Benjamin Popoff ${ }^{3}$, Adrien Picod ${ }^{1}$, \\ Regis Cohen ${ }^{4}$, Frank Chemouni ${ }^{5}$, Stephane Gaudry ${ }^{1,6}$, Helene Bihan ${ }^{2}$ and Yves Cohen ${ }^{1}$
}

\section{Correction to: Ann Intensive Care (2020) 10:58} https://doi.org/10.1186/s13613-020-00676-6 After publication of the original article [1], the authors would like to correct a percentage in the Abstract paragraph, under the heading "Results".

The sentence currently reads: "At admission, procalcitonin (median: $3.58 \mathrm{ng} / \mathrm{mL}$ vs $0.52 \mathrm{ng} / \mathrm{mL}, \mathrm{p}<0.001$ ) and presence of fever $(25 \%$ vs $44 \%, \mathrm{p}=0.007)$ were different between episodes with and without proven bacterial infection in both univariate and multivariate analysis".

The sentence should read: "At admission, procalcitonin (median: $3.58 \mathrm{ng} / \mathrm{mL}$ vs $0.52 \mathrm{ng} / \mathrm{mL}, \mathrm{p}<0.001$ ) and presence of fever $(25 \%$ vs $4 \%, \mathrm{p}=0.007)$ were different between episodes with and without proven bacterial infection in both univariate and multivariate analysis".

The original article [1] has been updated.
France. ${ }^{5}$ Gustave Roussy, Médecine Intensive Réanimation, 94805 Villejuif, France. ${ }^{6}$ Sorbonne University, INSERM, Remodeling and Repair of Renal Tissue, UMR S1155, Tenon Hospital, Paris, France.

Published online: 02 June 2020

\section{Reference}

1. Blanchard F, Charbit J, Van der Meersch G, Popoff B, Picod A, Cohen R, Chemouni F, Gaudry S, Bihan H, Cohen Y. Early sepsis markers in patients admitted to intensive care unit with moderate-to-severe diabetic ketoacidosis. Ann. Intensive Care. 2020;10:58. https://doi.org/10.1186/s1361 3-020-00676-6.

\section{Publisher's Note}

Springer Nature remains neutral with regard to jurisdictional claims in published maps and institutional affiliations.

\begin{abstract}
Author details
${ }^{1}$ Medical-Surgical Intensive Care Unit, Avicenne University Hospital, AP-HP, Paris 13 University, Sorbonne Paris Cité, 125 rue Stalingrad, 93000 Bobigny, France. ${ }^{2}$ Department of Endocrinology, Diabetology, Metabolic Disease, Avicenne University Hospital, AP-HP, Paris 13 University, Sorbonne Paris Cité, CRNH-IdF, 125 rue Stalingrad, Bobigny, France. ${ }^{3}$ Department of Anesthesiology and Critical Care, Rouen University Hospital, Rouen, France. ${ }^{4}$ Department of Endocrinology, Delafontaine Hospital, 2 rue du Dr Delafontaine, Saint-Denis,
\end{abstract}

The original article can be found online at https://doi.org/10.1186/s1361 3-020-00676-6.

*Correspondence: fblancha@gmail.com

${ }^{\dagger}$ Florian Blanchard and Judith Charbit contributed equally to this work

${ }^{1}$ Medical-Surgical Intensive Care Unit, Avicenne University Hospital, AP-HP, Paris 13 University, Sorbonne Paris Cité, 125 rue Stalingrad,

93000 Bobigny, France

Full list of author information is available at the end of the article adaptation, distribution and reproduction in any medium or format, as long as you give appropriate credit to the original author(s) and the source, provide a link to the Creative Commons licence, and indicate if changes were made. The images or other third party material in this article are included in the article's Creative Commons licence, unless indicated otherwise in a credit line to the material. If material is not included in the article's Creative Commons licence and your intended use is not permitted by statutory regulation or exceeds the permitted use, you will need to obtain permission directly from the copyright holder. To view a copy of this licence, visit http://creativecommons.org/licenses/by/4.0/. 